\title{
ADAPTABILITY OF QUINOA GENOTYPES TO ALTITUDES AND POPULATION DENSITIES IN COLOMBIA
}

\author{
ADAPTAÇÃO DE GENÓTIPOS DE QUINOA EM ALTITUDES E DENSIDADES DE \\ PLANTIO NA COLOMMBIA
}

\author{
Wilson ANCHICO ${ }^{1^{*}}$; Carlos Roberto SPEHAR $^{1}$; Michelle Souza VILELA ${ }^{1}$ \\ 1. Faculty of Agronomy and Veterinary Medicine, University of Brasília, Brasília, DF, Brazil. *anchico20@hotmail.com
}

\begin{abstract}
This work aimed at evaluating and comparing agronomic characteristics of 15 quinoa (Chenopodium quinoa Willd) genotypes cultivated in two altitudes and sowing densities. The experiment initiated by individual plant selection in Brasília, DF, followed by progeny evaluation in Colombia, at $1,100 \mathrm{~m}$ and $1,850 \mathrm{~m}$ altitude and population densities of 30 and 12 plants $\mathrm{m}^{-1}$, with row spacing of $0,50 \mathrm{~m}$. Eleven progenies and four commercial cultivars were tested. The progenies were obtained by selecting individuals in BRS Syetetuba based on plant height, grain and dry matter yield, harvest index and 1,000 grain weight. The genotypes with the highest grain yield were BRQ $8\left(2,283 \mathrm{~kg} \mathrm{ha}^{-1}\right)$, Aurora $\left(2,121 \mathrm{~kg} \mathrm{ha}^{-1}\right)$ and BRQ $4(2,043$ $\mathrm{kg} \mathrm{ha}^{-1}$ ). In general, the genotypes had early plant cycle, from emergence to physiological maturity of 100-110 days at high plant density for the two altitudes. It is concluded that exploring variability in progenies originated from natural crosses is effective in the adaptation of quinoa to tropical environments. Moreover, genotypes tested in the Cerrado (Brazilian Savannah) maintain the same response relation when evaluated in Colombia.
\end{abstract}

KEYWORDS: Chenopodium quinoa Willd. Early maturity. Sustainable yield. Thermal index.

\section{INTRODUCTION}

Quinoa (Chenopodium quinoa Willd) has been continuously selected in the Andean Region, by gradual expansion from its probable center of origin, the outskirts of Titicaca Lake between Bolivia and Peru (MAUGHAN et al., 2004). It has spread out to the North (Ecuador, Colombia and Venezuela) and to the South (Chile and Argentina), covering the Andean Highlands (Altiplano), the valleys and the coastal areas. The quinoa dissemination has been slow, probably due to mutations with adaptability to the immense variability of soil and climate in the cultivation areas (BERTERO et al., 2004).

The resilience of underutilized plant species and their respective ability to adjust to unfavorable environmental conditions has been a key factor in facing climate changes. This is expected from quinoa, a promising crop to play a relevant role in the years to come (BHARGAVA; DEEPAK, 2014). This species has shown considerable plasticity, developing in areas ranging from the sea level to $4,000 \mathrm{~m}$, low annual rainfall $(100-300 \mathrm{~mm})$, soil salinity $(0-300 \mathrm{mM} \mathrm{NaCl})$, low temperatures (BAZILE; BERTERO; NIETO, 2014). Moreover, the global climatic changes, reducing availability and quality of water shall compromise crop performance worldwide, creating opportunities for crops such as quinoa (COULIBALY et al., 2014).
It has been shown that quinoa survives at $7,8^{\circ} \mathrm{C}$ in $2,245 \mathrm{~m}$ above the sea level areas in Mexico, tolerating a range of soil $\mathrm{pH}$, from acid to alkaline, characteristics that can classify this species as resistant to climate changes, with other species like broad bean, maize, grain amaranth and onion (BOJANIC, 2011).

On the development of sustainable cropping systems, quinoa could act as soil protecting crop in no-till systems, due to its high biomass yields (SPEHAR, 2007). It requires low amount of seeds for sowing and can be introduced as an option for diversification of agriculture and food. Therefore, quinoa becomes attractive to farmers and consumers interested on diet improvement.

In Brazil, the first attempts of introducing quinoa took place in the 1990's, by selecting and evaluating progenies of hybrids that showed late maturity in high altitudes. The introduction and further selection originated the first genotypes for the Cerrado region (Brazilian Savannah) (SPEHAR; SOUZA 1993, SPEHAR 2007; SPEHAR; ROCHA; SANTOS, 2011). These evaluations identified the potentials of quinoa and the germplasm was enlarged by introductions from the United States, including large-seeded and saponin-free valley type accessions. The relatively high cross pollination rate was identified, allowing the recovery of progenies from hybrid plants. In the selection process, BRS Piabiru and BRS Syetetuba cultivars were obtained 
Adaptability of quinoa...

ANCHICO, W.; SPEHAR, C. R.; VILELA, M. S.

in the 2000's first decade, enlarging the interest for quinoa in Brazil (SPEHAR et al., 2014).

In Colombia, quinoa has been cultivated in the Cauca, Boyaca and Nariño Departments, where it is processed at family farming, of which $80 \%$ are destined to trading and 20\% saved for domestic use as food and seed (COLÔMBIA, 2016). Quinoa has become an asset of importance due to its adaptability to different cropping systems, nutritional quality and low production cost. It has become an option for sustainable production with economic benefits, by increasing the standard of living of indigenous populations (CARVAJAL, 2015).

In Colombia, however, quinoa has been grown at altitudes superior to $2,000 \mathrm{~m}$, utilizing low seed densities, not considering the crop adaptability to different agro environmental conditions of potential cropping regions in the country. This work aimed to evaluate the biometry and some agronomic characteristics of 15 quinoa (Chenopodium quinoa Will) genotypes, at two altitudes $(1,100 \mathrm{~m}$ and $1,850 \mathrm{~m})$, combining with two population densities (30 plants $\mathrm{m}^{-1}$ and 12 plants $\mathrm{m}^{-1}$ ), from Brazilian selection and experimentation in Colombia.

\section{MATERIAL AND METHODS}

Some activities were undertaken in Brazil and others in Colombia. In Brazil, the multiplication and selection of progenies was carried out by selecting plants from natural crosses between BRS Syetetuba and other genotypes evaluated in the Cerrado region (ROCHA, 2011). The experiment in Brazil was conducted in the Água Limpa Farm (FAL), Universidade de Brasília (UnB), Federal District, at an altitude of $1,100 \mathrm{~m}$, located at $15^{\circ} 56^{\prime}$ $\mathrm{S}$ and $47^{\circ} 55^{\prime} \mathrm{W}$. According to Köeppen, the climate is classified as Aw, with a rainy season, from October to March and a dry season, from April to September (KOTTEK et al., 2006).

\section{Progeny Selection in Brazil}

In the year 2017, individual plants were selected in FAL/UnB, by sowing BRS Syetetuba from seeds obtained locally, at $0.50 \mathrm{~m}$ row spacing. Individual plants, from natural crosses, identified by morphological agronomic characters, were harvested. Eleven progenies were selected considering earliness, grain size and color, panicle size and morphology, whether branched or compact (WAHLI, 1990) for evaluation in Colombia.

\section{Experiments in Colombia}

Evaluations in Colombia included 15 genotypes, representing 11 progenies selected in Brazil and the following four commercial cultivars: Blanca Dulce de Jerico and Aurora, from Colombia, and Tunkahuan and Piartal, from Ecuador. Two localities with potential for quinoa crop were chosen: Ecoaldea Fundamor, municipality of Santander de Quilichao, 1,100 m altitude, $3^{\circ} 0^{\prime} 30^{\prime \prime} \mathrm{N}$ and $76^{\circ} 29^{\prime} 2^{\prime \prime} \mathrm{W}$ (QUILICHAO, 2016); Prosperidad Farm, Municipality of Popayán, 1,850 $m$ altitude, $2^{\circ} 27{ }^{\prime} \mathrm{N}$ and $76^{\circ} 37^{\prime} 18^{\prime \prime} \mathrm{W}$ (POPAYÁN, 2016). The mean temperatures during the experiment at both localities were $21^{\circ}$ e $16^{\circ} \mathrm{C}$, respectively.

According to the soil analysis results, thirty days before sowing, the soil was prepared with the addition of lime $\left(2 \mathrm{t} \mathrm{ha}^{-1}\right)$ and organic fertilizer at a rate of $10 \mathrm{tha}^{-1}$.

\section{Experimental Design}

The experiments were conducted on splitplot complete randomized blocks design in each location. Each plot (genotype) was divided into two densities: 12 plants $\mathrm{m}^{-1}$ and 30 plants $\mathrm{m}^{-1}$. The subplot consisted of four rows of $1.0 \mathrm{~m}$ length, with harvesting area of $0.9 \mathrm{~m}^{2}$. For statistical analysis purposes, the program Genes was used and the means separated by Tukey and Scott and Knott tests, at 5\% probability (CRUZ, 2013).

\section{Phenological evaluations}

The following parameters were evaluated: time to emergence $(50 \%$ of the plantlets visible on the ground), time for the beginning of panicle formation $(50 \%$ of the plants starting the panicle emission), time for flowering ( $>50 \%$ of plants at anthesis), time for physiological maturity (from emergence to grains at farinaceous consistency).

\section{Determination of Degree Days or Thermal accumulation}

The sum of degree days (DD) was done for the four growing phases of quinoa, in both locations, using the formula:

$$
D D=\sum\left[\frac{\text { Max }+ \text { Min }}{2}\right]-B
$$

where $M a x=$ maximum daily temperature, Min=minimum daily temperature and $\mathrm{B}=$ basal temperature.

The basal temperature, below which the plant stop to growth, has been defined as $3.1{ }^{\circ} \mathrm{C}$ for quinoa Andean varieties (BERTERO, 2003). 
In Prosperidad Farm, data on temperature were collected from Procuenca Rio las Piedras Foundation, Popayán Municipality and Guillermo León Valencia Airport. In Ecoaldea Fundamor, data came from Centro de Investigación de la Caña de Azucar de Colombia - "CENICAÑA", in addition to field evaluation with mercury thermometer (Brixco®). The minimum and maximum temperatures were taken at the same time every day during the crop cycle.

\section{Agronomic Evaluation}

The agronomic characteristics evaluated were: plant height $(\mathrm{PH})$, panicle length $(\mathrm{PL})$ were based on ten random plants in the harvest area; plant dry matter (PDM), grain yield (GY) and 1,000 grain weight (TGW) were obtained from drying the harvested plants until constant weight, corrected to $13 \%$ moisture, harvest index (HI \%).

\section{RESULTS}

The overall thermal accumulation, measured in degree days for plant cycle, was 2,181 GD, corresponding to 111 days from emergence to physiological maturity. The earliest maturion genotypes were Aurora ((971.51 GD), BRQ1 (976 GD) and BRQ4 (993 GD), while BRQ 3 (1094 GD), BRQ 6 (1,105 GD) and BRQ 9 (1,078 GD) were the latest ones (Table 1).

The thermal accumulation for flowering showed lower values for Aurora (1,123 GD), BRQ1 $(1,137 \mathrm{GD})$ and BRQ4 (1,174 GD) genotypes, contrasting with BRQ 2 (1287 GD), BRQ 3 (1266 GD) and BRQ $9(1,261 \mathrm{GD})$ with the highest values. These differences allowed grouping the genotypes in early middle-cycle and late maturion, in the two locations.

The early maturation genotypes from beginning of panicle formation to physiological maturity had thermal accumulation of 1,932.56 GD (Aurora), 1,906.28 GD (BRQ1) and 1,929.28 GD (BRQ4). The late maturation genotypes showed thermal accumulation of 2,378.07 GD (BRQ 9), 2,325.97 GD (BRQ10) and 2,326.01 GD (Tunkahuan). Differences between treatments were observed (local/sowing density) by the Tukey test at $5 \%$ probability, where the highest precocity (917 GD) was achieved for panicle formation at $1,100 \mathrm{~m}$, on 30 plants $\mathrm{m}^{-1}$ density, in contrast with the 12 plant $\mathrm{m}^{-1}$ density at $1,850 \mathrm{~m}(1,177 \mathrm{GD})$ (Table 2$)$.

Table 1. Genotype means for days and thermal accumulation in the locations and sowing densities, for beginning of panicle formation (PF), flowering (FL) and physiological maturity (PM).

\begin{tabular}{lllllll}
\hline Genotype & PF & \multicolumn{1}{l}{ FL } & PM \\
\hline & Days & GD & Days & GD & \multicolumn{1}{l}{ Days } & GD \\
BRQ 1 & $46.37 \mathrm{a}$ & $0976.87 \mathrm{~b}$ & $55.06 \mathrm{c}$ & $1,137.70 \mathrm{~b}$ & $095.87 \mathrm{c}$ & $1,906.28 \mathrm{c}$ \\
BRQ 2 & $51.62 \mathrm{a}$ & $1,070.73 \mathrm{a}$ & $63.18 \mathrm{a}$ & $1,287.71 \mathrm{a}$ & $115.00 \mathrm{a}$ & $2,239.15 \mathrm{~b}$ \\
BRQ 3 & $52.87 \mathrm{a}$ & $1,094.86 \mathrm{a}$ & $62.50 \mathrm{a}$ & $1,266.85 \mathrm{a}$ & $111.25 \mathrm{~b}$ & $2,161.13 \mathrm{~b}$ \\
BRQ 4 & $47.43 \mathrm{a}$ & $993.61 \mathrm{~b}$ & $57.75 \mathrm{~b}$ & $1,174.95 \mathrm{~b}$ & $97.56 \mathrm{c}$ & $1,929.28 \mathrm{c}$ \\
BRQ 5 & $51.18 \mathrm{a}$ & $1,062.46 \mathrm{a}$ & $61.06 \mathrm{a}$ & $1,238.78 \mathrm{a}$ & $115.00 \mathrm{a}$ & $2,239.15 \mathrm{~b}$ \\
BRQ 6 & $53.37 \mathrm{a}$ & $1,105.68 \mathrm{a}$ & $62.93 \mathrm{a}$ & $1,277.90 \mathrm{a}$ & $115.00 \mathrm{a}$ & $2,239.15 \mathrm{~b}$ \\
BRQ 7 & $52.00 \mathrm{a}$ & $1,060.48 \mathrm{a}$ & $61.37 \mathrm{a}$ & $1,242.30 \mathrm{a}$ & $115.00 \mathrm{a}$ & $2,239.15 \mathrm{~b}$ \\
BRQ 8 & $50.31 \mathrm{a}$ & $1,052.37 \mathrm{a}$ & $59.12 \mathrm{a}$ & $1,211.90 \mathrm{a}$ & $109.68 \mathrm{~b}$ & $2,169.53 \mathrm{~b}$ \\
BRQ 9 & $52.00 \mathrm{a}$ & $1,078.23 \mathrm{a}$ & $62.31 \mathrm{a}$ & $1,261.35 \mathrm{a}$ & $121.50 \mathrm{a}$ & $2,378.07 \mathrm{a}$ \\
BRQ 10 & $51.93 \mathrm{a}$ & $1,076.10 \mathrm{a}$ & $61.93 \mathrm{a}$ & $1,253.61 \mathrm{a}$ & $119.06 \mathrm{a}$ & $2,325.97 \mathrm{a}$ \\
BRQ 11 & $50.12 \mathrm{a}$ & $1,042.38 \mathrm{a}$ & $60.56 \mathrm{a}$ & $1,235.91 \mathrm{a}$ & $116.12 \mathrm{a}$ & $2,273.95 \mathrm{a}$ \\
AURORA & $46.12 \mathrm{a}$ & $971.51 \mathrm{~b}$ & $54.31 \mathrm{c}$ & $1,123.51 \mathrm{~b}$ & $097.25 \mathrm{c}$ & $1,932.56 \mathrm{c}$ \\
TUNKAHUAN & $50.31 \mathrm{a}$ & $1,044.76 \mathrm{a}$ & $61.25 \mathrm{a}$ & $1,243.48 \mathrm{a}$ & $118.81 \mathrm{a}$ & $2,326.01 \mathrm{a}$ \\
PIARTAL & $51.37 \mathrm{a}$ & $1,067.95 \mathrm{a}$ & $59.25 \mathrm{a}$ & $1,212.70 \mathrm{a}$ & $109.87 \mathrm{~b}$ & $2,176.45 \mathrm{~b}$ \\
\hline Overall Mean & $\mathbf{5 0 . 5 0}$ & $\mathbf{1 , 0 4 9 . 8 6}$ & $\mathbf{6 0 . 1 9}$ & $\mathbf{1 , 2 2 6 . 3 4}$ & $\mathbf{1 1 1 . 1 0}$ & $\mathbf{2 , 1 8 1 . 1 3}$ \\
\hline CV\% & $\mathbf{4 . 5 5}$ & $\mathbf{3 . 9 5}$ & $\mathbf{4 . 6 5}$ & $\mathbf{4 . 0 6}$ & $\mathbf{7 . 6 5}$ & $\mathbf{7 . 0 1}$ \\
\hline Bras
\end{tabular}

Brasília, DF, 2018; ${ }^{1}$ Means followed by the same letter on the column are not statistically different (Scott and Knott test, $5 \%$ probability).

When genotypes are compared for flowering, earliness was observed in the $1,100 \mathrm{~m}$ location for 30 plants $\mathrm{m}^{-1}$ density, with overall mean of $1,093 \mathrm{GD}$. In the $1,850 \mathrm{~m}$ location, at 12 plants $\mathrm{m}^{-1}$ the mean value was 1348 GD (Table 2).
The yield components did not show significant differences among genotypes, with a trend of higher panicle length for BRQ 8, Aurora and Piartal, contrasting with the lowest values for BRQ 1 and BRQ 9. 
Table 2. Mean values for location (L) and sowing density (SD) of number of days and thermal accumulation (GD) to emergence (E), panicle formation (PF), flowering (FL) and physiological maturity (PM).

\begin{tabular}{lllllllll} 
L/SD & E & \multicolumn{3}{l}{ PF } & \multicolumn{3}{c}{ FL } & \multicolumn{2}{c}{ PM } \\
\hline & Days & GD & Days & GD & Days & GD & Days & GD \\
\cline { 2 - 8 } $\mathbf{1}$ & 6 & $97.91 \mathrm{a}$ & $65.87 \mathrm{a}$ & $1,177.35 \mathrm{a}$ & $68.10 \mathrm{a}$ & $1,348.86 \mathrm{a}$ & $119.50 \mathrm{a}$ & $2,190.92 \mathrm{a}$ \\
$\mathbf{2}$ & 6 & $97.91 \mathrm{a}$ & $56.23 \mathrm{a}$ & $1,168.17 \mathrm{a}$ & $66.44 \mathrm{a}$ & $1,332.69 \mathrm{a}$ & $117.48 \mathrm{a}$ & $2,158.44 \mathrm{a}$ \\
$\mathbf{3}$ & 4 & $80.33 \mathrm{~b}$ & $44.82 \mathrm{a}$ & $936.53 \mathrm{~b}$ & $53.98 \mathrm{~b}$ & $1,130.35 \mathrm{~b}$ & $106.00 \mathrm{~b}$ & $2,231.48 \mathrm{a}$ \\
$\mathbf{4}$ & 4 & $80.33 \mathrm{~b}$ & $43.92 \mathrm{a}$ & $917.37 \mathrm{~b}$ & $52.21 \mathrm{~b}$ & $1,093.43 \mathrm{~b}$ & $101.87 \mathrm{~b}$ & $2,143.68 \mathrm{a}$ \\
\hline Overall Mean & 5 & 89,12 & 52,71 & 1049,85 & 60,18 & 1226,33 & 111,21 & 2181,13 \\
\hline CV\% & 23,09 & 11,39 & 19,74 & 13,54 & 13,70 & 10,85 & 7,74 & 1,78 \\
\hline
\end{tabular}

Brasília, DF, 2018; ${ }^{1}$ Means followed by the same letter on the column are not statistically different (Tukey $5 \%$ probability). ${ }^{2} 1: 1,850 \mathrm{~m}$ +12 plants $\mathrm{m}^{-1} ; 2: 1,850 \mathrm{~m}+30$ plants $\mathrm{m}^{-1} ; 3: 1,100 \mathrm{~m}+12$ plants $\mathrm{m}^{-1} ; 4: 1,100 \mathrm{~m}+30$ plants $\mathrm{m}^{-1}$.

As for the plant characteristics measurements, panicle length was higher in the Ecoaldea Fundamor $(1,100 \mathrm{~m})$ at 12 plants $\mathrm{m}^{-1}$ density. Similarly, biomass yield was attained on the same location and density, varying between 6,796 and $8,625 \mathrm{~kg} \mathrm{ha}^{-1}$. The highest biomass yielding genotypes were Aurora $\left(8,625 \mathrm{~kg} \mathrm{ha}^{-1}\right)$ and BRQ 8 $\left(8,169.9 \mathrm{~kg} \mathrm{ha}^{-1}\right)$, while the lowest was observed in
BRQ $11\left(6,426.8 \mathrm{~kg} \mathrm{ha}^{-1}\right)$ and BRQ $9(6,389.8 \mathrm{~kg}$ $\mathrm{ha}^{-1}$ ) (Table 3). Grain yield varied between $2,283 \mathrm{~kg}$ $\mathrm{ha}^{-1}$ (BRQ 8) and 1,318 $\mathrm{kg} \mathrm{ha}^{-1}$ (Tunkahuan). Aurora, selected in the Universidad de Nariño, produced $2,121 \mathrm{~kg}$ of grains.ha ${ }^{-1}$. The highest grain yields were harvested in Prosperidad Farm, independently of the plant density.

Table 3. Mean values of location and sowing density for the following yield characteristics: plant height (PH, $\mathrm{cm})$, panicle length $(\mathrm{PL}, \mathrm{cm})$, grain yield $\left(\mathrm{GY}, \mathrm{Kg} . \mathrm{ha}^{-1}\right)$, plant dry matter (DMY, Kg. ha $\left.{ }^{-1}\right)$, harvest index (HI, \%) and 1,000 seed weight (TGW, g/1,000).

\begin{tabular}{lllllll} 
L/SD & PH & PL & GY & DMY & HI & TGW \\
\hline $\mathbf{1}$ & $117.70 \mathrm{a}$ & $27.59 \mathrm{a}$ & $1,554.36 \mathrm{c}$ & $6,205.02 \mathrm{~b}$ & $25.08 \mathrm{~b}$ & $2.60 \mathrm{a}$ \\
$\mathbf{2}$ & $119.17 \mathrm{a}$ & $25.88 \mathrm{a}$ & $2,371.56 \mathrm{a}$ & $8,184.65 \mathrm{a}$ & $29.49 \mathrm{a}$ & $2.62 \mathrm{a}$ \\
$\mathbf{3}$ & $144.50 \mathrm{a}$ & $35.70 \mathrm{a}$ & $1,325.66 \mathrm{c}$ & $5,928.57 \mathrm{~b}$ & $22.30 \mathrm{~b}$ & $2.27 \mathrm{~b}$ \\
$\mathbf{4}$ & $141.78 \mathrm{a}$ & $33.81 \mathrm{a}$ & $1,960.31 \mathrm{~b}$ & $9,201.45 \mathrm{a}$ & $21.37 \mathrm{~b}$ & $2.26 \mathrm{~b}$ \\
\hline Overall Mean & $\mathbf{1 3 0 , 7 9}$ & $\mathbf{3 0 , 7 5}$ & $\mathbf{1 8 0 2 , 9 7}$ & $\mathbf{7 3 7 9 , 9 2}$ & $\mathbf{2 4 , 5 6}$ & $\mathbf{2 , 4 4}$ \\
\hline CV\% & $\mathbf{1 0 , 9 5}$ & $\mathbf{1 5 , 4 4}$ & $\mathbf{2 5 , 5 7}$ & $\mathbf{2 1 , 3 6}$ & $\mathbf{1 4 , 8 4}$ & $\mathbf{8 , 1 8}$ \\
\hline
\end{tabular}

Brasília, DF, 2018; ${ }^{1}$ Means followed by the same letter in the column are not statistically different (Tukey test, $5 \%$ probability). ${ }^{2} 1$ : $1,850 \mathrm{~m}+12$ plants $\mathrm{m}^{-1} ; 2: 1,850 \mathrm{~m}+30$ plants $\mathrm{m}^{-1} ; 3: 1,100 \mathrm{~m}+12$ plants $\mathrm{m}^{-1} ; 4: 1,100 \mathrm{~m}+30$ plants $\mathrm{m}^{-1}$.

Table 4. Mean genotype values over location and sowing density for plant height ( $\mathrm{PH}, \mathrm{cm})$, panicle length (PL, $\mathrm{cm})$, grain yield $\left(\mathrm{GY}, \mathrm{Kg} . \mathrm{ha}^{-1}\right)$, plant dry matter (DMY, Kg. ha $\left.{ }^{-1}\right)$, harvest index (HI, \%) and 1,000 seed weight (TGW, g/1,000).

\begin{tabular}{lllllll}
\hline Genotype & PH & PL & GY & DMY & HI & TGW \\
\hline BRQ 1 & $106.51 \mathrm{a}$ & $26.15 \mathrm{a}$ & $1,895.83 \mathrm{c}$ & $6,526.39 \mathrm{c}$ & $29.70 \mathrm{a}$ & $2.68 \mathrm{a}$ \\
BRQ 2 & $130.70 \mathrm{a}$ & $29.59 \mathrm{a}$ & $1,895.83 \mathrm{c}$ & $7,578.26 \mathrm{~b}$ & $24.96 \mathrm{~b}$ & $2.50 \mathrm{a}$ \\
BRQ 3 & $141.53 \mathrm{a}$ & $32.10 \mathrm{a}$ & $1,576.36 \mathrm{~d}$ & $7,458.33 \mathrm{~b}$ & $21.21 \mathrm{c}$ & $2.44 \mathrm{a}$ \\
BRQ 4 & $121.79 \mathrm{a}$ & $28.78 \mathrm{a}$ & $2,043.05 \mathrm{~b}$ & $7,374.99 \mathrm{~b}$ & $27.83 \mathrm{a}$ & $2.47 \mathrm{a}$ \\
BRQ 5 & $127.41 \mathrm{a}$ & $29.77 \mathrm{a}$ & $1,971.29 \mathrm{c}$ & $8,086.57 \mathrm{a}$ & $24.85 \mathrm{~b}$ & $2.44 \mathrm{a}$ \\
BRQ 6 & $131.94 \mathrm{a}$ & $30.76 \mathrm{a}$ & $1,944.44 \mathrm{c}$ & $7,840.27 \mathrm{~b}$ & $26.58 \mathrm{~b}$ & $2.59 \mathrm{a}$ \\
BRQ 7 & $129.05 \mathrm{a}$ & $29.37 \mathrm{a}$ & $1,784.72 \mathrm{c}$ & $6,796.29 \mathrm{c}$ & $26.02 \mathrm{~b}$ & $2.54 \mathrm{a}$ \\
BRQ 8 & $145.02 \mathrm{a}$ & $34.18 \mathrm{a}$ & $2,283.33 \mathrm{a}$ & $8,169.90 \mathrm{a}$ & $27.83 \mathrm{a}$ & $2.51 \mathrm{a}$ \\
BRQ 9 & $131.67 \mathrm{a}$ & $26.91 \mathrm{a}$ & $1,446.76 \mathrm{~d}$ & $6,389.81 \mathrm{c}$ & $21.31 \mathrm{c}$ & $2.51 \mathrm{a}$ \\
BRQ 10 & $135.08 \mathrm{a}$ & $30.53 \mathrm{a}$ & $1,553.24 \mathrm{~d}$ & $6,791.66 \mathrm{c}$ & $23.34 \mathrm{c}$ & $2.54 \mathrm{a}$ \\
BRQ 11 & $134.06 \mathrm{a}$ & $27.93 \mathrm{a}$ & $1,868.05 \mathrm{c}$ & $6,426.85 \mathrm{c}$ & $29.14 \mathrm{a}$ & $2.39 \mathrm{a}$ \\
AURORA & $123.21 \mathrm{a}$ & $34.92 \mathrm{a}$ & $2,121.29 \mathrm{~b}$ & $8,625.00 \mathrm{a}$ & $24.36 \mathrm{~b}$ & $2.35 \mathrm{a}$ \\
TUNKAHUAN & $134.48 \mathrm{a}$ & $34.39 \mathrm{a}$ & $1,318.05 \mathrm{~d}$ & $7,163.42 \mathrm{c}$ & $18.89 \mathrm{~d}$ & $2.03 \mathrm{~b}$ \\
PIARTAL & $138.61 \mathrm{a}$ & $35.06 \mathrm{a}$ & $1,539.35 \mathrm{~d}$ & $8,091.20 \mathrm{a}$ & $18.12 \mathrm{~d}$ & $2.16 \mathrm{~b}$ \\
\hline Overall Mean & $\mathbf{1 3 0 . 7 9}$ & $\mathbf{3 0 . 7 5}$ & $\mathbf{1 , 8 0 2 . 9 8}$ & $\mathbf{7 , 3 7 9 . 9 3}$ & $\mathbf{2 4 . 5 9}$ & $\mathbf{2 . 4 4}$ \\
\hline CV\% & $\mathbf{7 . 2 4}$ & $\mathbf{9 . 6 6}$ & $\mathbf{1 5 . 4 2}$ & $\mathbf{9 . 7 9}$ & $\mathbf{1 4 . 7 9}$ & $\mathbf{6 . 9 9}$ \\
\hline
\end{tabular}

Brasília, DF, 2018; ${ }^{1}$ Means followed by the same letter are not statistically different (Scott and Knott, 5\% probability). 
Adaptability of quinoa...

Harvest index varied between $29.70 \%$ (BRQ 1), that did not differ of BRQ 4, BRQ 8 and BRQ 11 to the lowest levels in Tunkahuan $(18.12 \%)$, which was not different from cultivar Piartal (Table 4). The seed weight varied between $2.68 \mathrm{~g}$ and $2.03 \mathrm{~g}$, with highest values shown by BRQ 1, BRQ 6, BRQ 7, BRQ 9, BRQ 10 and BRQ 8while Piartal and Tunkahuan had the lowest $2.15 \mathrm{~g}$ and $2.02 \mathrm{~g}$ respectively.

\section{DISCUSSION}

In general, quinoa genotypes showed early maturity cycle at $1,100 \mathrm{~m}$ location in Colombia, which was related to higher temperatures, with similar performance in the Cerrado Highlands of Brazil, compared to $1,850 \mathrm{~m}$ of altitude, confirming results obtained by SANTOS (1996) about the effects of altitude on the number of days from emergence to maturity. These data were also corroborated by trials in Denmark with Chilean genotypes at temperatures of 30 and $35^{\circ} \mathrm{C}$, which reduced the time for germination and emergence (JACOBSEN; BACH, 1998). In another experiment, when the quinoa seeds were incubated at $2^{\circ} \mathrm{C}$, the germination time increased between 45 and 67 hours (BERTERO, 2014). The combination of temperature and salinity confirmed that the germination speed was higher at $20^{\circ} \mathrm{C}$ than at $5^{\circ}$ $\mathrm{C}$, for the Cica and Real varieties (CHILO et al., 2009).

Therefore, accumulated degree days have influenced germination speed in quinoa (BERTERO, 2001). In this experiment, regardless of the planting density, all genotypes anticipated maturity probably due to the conditions of lower altitude than those of the origin of the materials (WAHLI, 1990).

Colombian quinoa (Aurora), although selected from higher altitude accessions, showed similar germination levels at mean temperatures of $21^{\circ} \mathrm{C}$ for $1,100 \mathrm{~m}$ and $16^{\circ} \mathrm{C}$ for $1,850 \mathrm{~m}$. On the other hand, the studies indicated that germination in quinoa has been impaired by temperatures above 30 ${ }^{\circ} \mathrm{C}$ (BERTERO; KING; HALL, 1999a).

At the density of 30 plants $m-1$, the grain yield was higher than 12 plants $\mathrm{m}-1$ explained by a greater uniformity of the crop and a greater survival of the plants. These results are corroborated by experiments carried out in Argentina, where when testing densities of 22, 33 and 66 plants $\mathrm{m}^{-2}$, they found higher values of biomass and grain yield in the design of a greater number of plants per $\mathrm{m}^{-2}$ (BERTERO; RUIZ, 2008).
Within certain limits approximately (700,000 plants $\mathrm{ha}^{-1}$ ), a positive correlation between plant density and yield has been demonstrated for quinoa (SPEHAR; ROCHA, 2009). Furthermore, regardless of the population density and sowing patterns, the number of grains per plant is the main component of quinoa yield (BERTERO; RUIZ, 2008; CURTI et al., 2014).

In Ecoaldea Fundamor $(1,100 \mathrm{~m})$, it was confirmed that high temperatures reduces grain yield. The most sensitive phase of plant development in quinoa is the flowering period, with a big impact on grain yields (BERTERO; RUIZ, 2008). Although plants of quinoa showed higher growth at the low altitude $(1,100 \mathrm{~m})$, grain yield was higher at $1,850 \mathrm{~m}$ (Table 3 ). Similar conclusions were reached by Santos (1996) that high temperatures induces fast plant growth but lower yields in quinoa genotypes, while plant cycle was not consistently reduced by the plant exposure to high temperatures (SANTOS, 1996).

In this work, the genotypic difference was demonstrated by the flowering time and grain yield, helping to understand the interaction of the environment (altitude and temperature) on the genotypes. In addition, it can indicate the agroecological adjustment of genotypes to specific growing environments (CURTI et al., 2014). The high genotypic variability observed here indicated the potential for plant reproduction for the adaptation of quinoa plants in a wide range of environments (BERTERO et al., 2004; POUTEAU et al., 2011; GEERTS et al., 2006; CURTI et al. al., 2012).

The highest biomass yield was observed in BRQ 8 and Aurora, which also had the highest grain yields (Table 4). So, biomass yield of these genotypes was related to grain yield, indicating they are valuable in breeding programs aiming for grain and forage purposes. Similar relationship was found in other studies with quinoa genotypes (BERTERO et al., 2004).

Accumulated degree days for physiological maturity did not show significant differences for both locals (Table 2). Therefore, when quinoa is sown under the same photoperiod conditions, what defines the phenological phases is a constant degree days value (BERTERO; KINGB; HALL, 1999b). This allows a more realistic comparison of genotypes for plant cycle, according to their temperature response.

The development of quinoa occurred at average temperatures of $16^{\circ} \mathrm{C}$ and $21^{\circ} \mathrm{C}$, with a basal temperature of $3{ }^{\circ} \mathrm{C}$, which illustrates the positive response to mild temperatures for grain 
Adaptability of quinoa...

ANCHICO, W.; SPEHAR, C. R.; VILELA, M. S.

yield (BOIS et al., 2006). Given this information, it is possible to combine the environmental conditions and the genotypic response for the quinoa crop, seeking to predict its cycle and grain yield.

\section{CONCLUSIONS}

Exploring genotypic variability in progenies of Andean Valley quinoa natural hybrids leads to acquiring progenies from BRS Syetetuba adaptable to tropical environment cultivation.

Selection for agronomic characteristics and yield is proven to be effective by evaluations in Brazil and Colombia.

Response to temperature explains the agroecological performance of quinoa genotypes selected in the Cerrado Highlands.
Number of seeds is the main determinant of the quinoa yield, in contrast to the low correlation of seed weight and yield.

The best yield results at the $1100 \mathrm{~m}$ site were for the BRS4 genotypes, BRS8 and Aurora.

The most outstanding genotypes for the $1850 \mathrm{~m}$ site were BRS8, BRS 1 and BRS 7

\section{ACKNOWLEDGEMENTS}

The author are grateful to the Universidade de Brasília (UnB), Post-graduation in Agronomy, for the support in the development of this research; to the Federal District Research Foundation (FAPDF) for the financial support; to Universidad Nacional de Colombia in Palmira, for financial support to field work; to Corporación Universitaria (Comfacauca) of Colombia, for lab and personal help.

RESUMO: Este trabalho teve por objetivo avaliar e comparar características agronômicas e biométricas de 15 genótipos de quinoa (Chenopodium quinoa Willd), cultivados em duas altitudes e densidades de semeadura. O experimento iniciou por seleção individual em Brasília, DF, seguido por avaliação

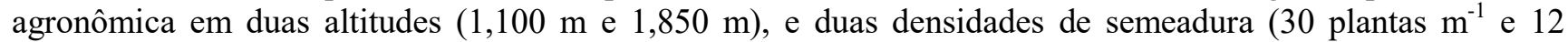
plantas $\mathrm{m}^{-1}$ ) na Colômbia. $\mathrm{O}$ experimento foi constituído por 11 progênies e quatro cultivares comerciais em uso na Colômbia. Na seleção, consideraram-se altura de plantas, produção de grãos e massa seca, índice de colheita e peso de 1000 grãos. Os genótipos que se destacaram para rendimento foram BRQ $8\left(2,283 \mathrm{~kg} \mathrm{ha}^{-1}\right)$, Aurora $\left(2,121 \mathrm{~kg} \mathrm{ha}^{-1}\right)$ e BRQ $4\left(2,043 \mathrm{~kg} \mathrm{ha}^{-1}\right)$. Em geral, os genótipos apresentaram precocidade, com ciclo (emergência-maturação) entre 100 e 110 dias, com densidade ótima de 30 plantas $\mathrm{m}^{-1}$ nas duas altitudes. Conclui-se que a exploração de variabilidade em progênies oriundas de cruzamentos naturais, mostra-se efetiva na adaptação de quinoa a ambientes tropicais. Ademais, genótipos selecionados no Cerrado mantêm as mesmas relações de resposta quando avaliados na Colômbia. sustentável.

PALAVRAS-CHAVE: Acumulação térmica. Chenopodium quinoa Willd. Precocidade. Produção

\section{REFERENCES}

BAZILE, D.; BERTERO, H. D.; NIETO, C. La quínoa en Chile. IN. BAZILE D. et al. (Ed.), 2014. Estado del arte de la quinua en el mundo en 2013: FAO (Santiago de Chile) y CIRAD, (Montpellier, Francia), p. 724, 2014.

BERTERO, H. D.; KING, R. W.; HALL, A. J. Photoperiod-sensitive development phases in quinoa (Chenopodium quinoa Willd.). Field Crops Research, v. 60, n. 3, p. 231-243, 1999a.

https://doi.org/10.1016/S0378-4290(98)00128-2

BERTERO, H. D.; KINGB, R. W.; HALL, A. J. Modelling photoperiod and temperature responses of flowering in quinoa (Chenopodium quinoa Willd.). Field Crops Research, v. 63, p. 19-34, 1999 b. https://doi.org/10.1016/S0378-4290(99)00024-6

BERTERO, H. D. Effects of photoperiod, temperature and radiation on the rate of leaf appearance in quinoa (Chenopodium quinoa Willd.) under field conditions. Annals of Botany, v. 87, n. 4, p. 495-502, 2001. https://doi.org/10.1006/anbo.2000.1362 
BERTERO, H. D. Response of developmental processes to temperature and photoperiod in quinoa (Chenopodium quinoa Willd.). Food Reviews International, v. 19, n. 1-2, p. 87-97, 2003. https://doi.org/10.1081/FRI-120018870

BERTERO, H. D.; DE LA VEGA, A. J.; CORREA, G.; JACOBSEN, S. E.; MUJICA, A. Genotype and genotype-by-environment interaction effects for grain yield and grain size of quinoa (Chenopodium quinoa Willd.) as revealed by pattern analysis of international multi-environment trials. Field Crops Research, v. 89, n. 2, p. 299-318, 2004. https://doi.org/10.1016/j.fcr.2004.02.006

BERTERO, H. D.; RUIZ, R. A. Determination of seed number in sea level quinoa (Chenopodium quinoa Willd.) cultivars. European journal of agronomy, v. 28, n. 3, p. 186-194, 2008. https://doi.org/10.1016/j.eja.2007.07.002

BERTERO, H. D. Control ambiental del desarrollo. IN. BAZILE D. et al. (Ed.), 2014. Estado del arte de la quinua en el mundo en 2013: FAO (Santiago de Chile) y CIRAD, (Montpellier, Francia), p. 724, 2014.

BHARGAVA, A.; DEEPAK, O. Quinua en el subcontinente indio. IN. BAZILE D. et al. (Ed.), 2014. Estado del arte de la quinua en el mundo en 2013: FAO (Santiago de Chile) y CIRAD, (Montpellier, Francia), p. 724, 2014.

BOIS, J. F.; WINKEL, T.; LHOMME, J. P.; RAFFAILLAC, J. P.; ROCHETEAU, A. Response of some Andean cultivars of quinoa (Chenopodium quinoa Willd.) to temperature: effects on germination, phenology, growth and freezing. European Journal of Agronomy, v. 25, n. 4, p. 299-308, 2006.

https://doi.org/10.1016/j.eja.2006.06.007

FAO - Oficina Regional para América Latina y el Caribe. La quinua: cultivo milenário para contribuir a la seguridad alimentaria mundial, Bolívia, 58p., 2011.

CARVAJAL, A. CIAT. Una visión compartida y un plan de acción para el futuro de la quinua en Colombia, 2015. Disponível em: <www.blog.ciat.cgiar.org/es/una-vision-compartida-y-un-plan-de-accionpara-el-futuro-de-la-quinua-en-colombia/>. Acesso em: 29 julho 2017.

CHILO, G.; VACCA MOLINA, M.; CARABAJAL, R.; OCHOA, M. Efecto de la temperatura y salinidad sobre la germinación y crecimiento de plántulas de dos variedades de Chenopodium quinoa. Agriscientia, v. 26, n. 1, p. 15-22, 2009. http://dx.doi.org/10.31047/1668.298x.v26.n1.2749

CRUZ, C.; D. Genes: a software package for analysis in experimental statistics and quantitative genetics. Acta Scientiarum. Agronomy, v. 35, n. 3, p. 271-276, 2013. https://doi.org/10.4025/actasciagron.v35i3.21251

COUliBAlY, A.; SANGARÉ, A.; KONATE, M.; TRAORÉ, S.; RUIZ, K. B.; MARTINEZ, E. A.; LÉON, P. Evaluación de Quinua (Chenopodium quinua Willd.) y adaptación a las condiciones agroclimáticas de Mali, África Oeste: Un ejemplo de colaboración Sur-Norte-Sur. IN. BAZILE D. et al. (Ed.), 2014. Estado del arte de la quinua en el mundo en 2013: FAO (Santiago de Chile) y CIRAD, (Montpellier, Francia), 2014. $724 \mathrm{p}$.

CURTI, R. N.; DE LA VEGA, A. J.; ANDRADE, A. J.; BRAMARDI, S. J.; BERTERO, H. D. Multienvironmental evaluation for grain yield and its physiological determinants of quinoa genotypes across Northwest Argentina. Field Crops Research, v. 166, p. 46-57, 2014. https://doi.org/10.1016/j.fcr.2014.06.011

CURTI, R. N.; ANDRADE, A. J.; BRAMARDI, S.; VELASQUEZ, B.; BERTERO, H. D. Ecogeographic structure of phenotypic diversity in cultivated populations of quinoa from Northwest Argentina. Annals of applied biology, v. 160, p. 114-125, 2012. https://doi.org/10.1111/j.1744-7348.2011.00524.X

CURTI, R. N.; DE LA VEGA, A. J.; ANDRADE, A. J.; BRAMARDI, S. J.; BERTERO, H. D. Adaptive responses of quinoa to diverse agro-ecological environments along an altitudinal gradient in North West Argentina. Field Crops Research, v. 189, p. 10-18. 2016. https://doi.org/10.1016/j.fcr.2016.01.014 
COLÔMBIA. Agronet. MinAgricultura fortalece agronegocios de 1.930 familias del Cauca - 20 de septiembre de 2016. Disponível em: $<\mathrm{http}$ //www.agronet.gov.co/Noticias/Paginas/MinAgricultura-fortaleceagronegocios-de-1-930-familias-del-Cauca-.aspx>. Acesso em: 28 de dezembro de 2016.

GEERTS, S.; RAES, D.; GARCIA, M.; DEL CASTILLO, C.; BUYTAERT, W. Agro-climaticsuitability mapping for crop production in the Bolivian Altiplano: a case studyfor quinoa. Agricultural and Forest Meteorology, v.139, p.399- 412, 2006. https://doi.org/10.1016/j.agrformet.2006.08.018

JACOBSEN, S. E.; BACH, A. The influence of temperature on seed germination rate in quinoa (Chenopodiumquinua Willd). Seed Science and Technology, v. 26, p. 515-523, 1998.

KOTTEK, M.; GRIESER, J.; BECK, C.; RUDOLF, B.; RUBEL, F. World map of the KöppenGeiger climate classification updated. Meteorologische Zeitschrift, v. 15, p. 259-263, 2006. https://doi.org/10.1127/0941$\underline{2948 / 2006 / 0130}$

MAUGHAN, P. J.; BONIFACIO, A.; JELLEN, E. N.; STEVENS, M. R.; COLEMAN, C. E.; RICKS, M.; FAIRBANKS, D. J. A genetic linkage map of quinoa (Chenopodium quinoa) based on AFLP, RAPD, and SSR markers. Theoretical and applied genetics, v. 109, p. 1188-1195, 2004. https://doi.org/10.1007/s00122-004$\underline{1730-9}$

POPAYÁN, A. M. D. Alcaldia Municipal de Popayán, 2016. Disponível em:

$<$ http://popayan.gov.co/ciudadanos/popayan/nuestra-geografia $>$. Acesso em: 3 de outubro de 2016.

POUTEAU, R.; RAMBAL, S.; RATTE, J. P.; GOGÉ, F.; JOFFRE, R.; WINKEL, T. Downscaling MODISderived maps using GIS and boosted regression trees: the case of frost occurrence over the arid Andean highlands of Bolivia. Remote Sensing of Environment, v. 115, n. 1, p. 117-129, 2011.

https://doi.org/10.1016/j.rse.2010.08.011

QUILICHAO, A. D. S. D. Información del Municipio, 2016. Disponivel em: $<$ http://santanderdequilichaocauca.gov.co/MiMunicipio/Paginas/Informacion-del-Municipio.aspx>. Acesso em: 16 out, 2017.

ROCHA, J. E. S. Controle genético de caracteres agronômicos em quinoa (Chenopodium quinoa Willd). 2011. 144 f. Tese (Doutorado em Agronomia) - Universidade de Brasília, Brasília 2011.

SANTOS, R. L. B. Estudos iniciais para cultivo de quinoa (Chenopodium quinoa Willd) no Cerrado. 1996. 129 f. Dissertação (Mestrado em Ciências Agrárias) - Universidade de Brasília, Brasília, 1996.

SPEHAR, C. R.; DE SOUZA; P. I. D. M. Adaptação da quinoa (Chenopodium quinoa Willd.) ao cultivo nos cerrados do Planalto Central: resultados preliminares. Pesquisa Agropecuária Brasileira, v. 28, p. 635-639, 1993.

SPEHAR, C. Quinoa: alternativa para a diversificação agrícola e alimentar. Planaltina, DF: Embrapa Cerrados, 2007.

SPEHAR, C.; ROCHA, J. E. S. Effect of sowing density on plant growth and development of quinoa, genotype 4.5, in the Brazilian savannah highlands. Bioscience Journal, v. 25, n. 4, p. 53-58, 2009.

SPEHAR, C. R.; ROCHA, J. E. S.; SANTOS, R. L. D. Desempenho agronômico e recomendações para cultivo de quinoa (BRS Syetetuba) no cerrado. Pesquisa Agropecuária Tropical, v. 41, 2011.

https://doi.org/10.5216/pat.v41i1.9395.

SPEHAR, C.; ROCHA, J. E. S.; RIBEIRO J. W. Q.; SANTOS, R. D. B.; ASCHERI, J; SOUZA, F. D. J. Avances y desafíos de la producción y utilización de la quinua en Brasil. IN. BAZILE D. et al. (Ed.), 2014. Estado del arte de la quinua en el mundo en 2013: FAO (Santiago de Chile) y CIRAD, (Montpellier, Francia), p. $724,2014$.

WAHLI, C. Quinua hacia su cultivo comercial. Latinreco, Quito, 206 p., 1990. 